\title{
Cyprus Peace Negotiations: (Neo)-imperialism is the deal breaker
}

Dr Ilia Xypolia ${ }^{1}$

The final definitive version of this paper has been published in The Round Table: The Commonwealth Journal of International Affairs by Taylor and Francis and is available on the journal website at:

http://www.tandfonline.com/doi/10.1080/00358533.2017.1306210

It has long been argued that a solution to the longstanding Cyprus issue would only come from within the island and not as a product of foreign imposition. Scholars who attribute the stalemate in Cyprus to individuals or clashing nationalistic aspirations often rush in raising hopes at the occasion of leaders committed to reach a solution. The last decade, when Christofias and Talat leftwing politicians who were sharing similar visions were elected, did not achieve much. It is therefore important to highlight that the deadlock is not simply a product of competing nationalisms or lack of willingness and commitment to a solution. Rather, it is a product of neo-imperialist framework of maintaining the parochial system of the 1958-1960 arrangements.

The initiatives taken by Nicos Anastasiades and Mustafa Akinci included 20month-long bilateral negotiations. Unlike in previous such parleys, both leaders appeared to be genuinely committed to reaching a solution, and have taken full control of the process, meeting nearly every week for the last part of 2016. Its development culminated into a UN-facilitated process in Geneva aimed at a comprehensive settlement. This multilateral conference, which for the first time included the European Union was prearranged to take place in 2017. The initial optimistic view was soon replaced by a more sceptical view of a complex and

\footnotetext{
${ }^{1}$ Dr Ilia Xypolia, Department of Politics \& International Relations University of Aberdeen, UK, e-mail: ilia.xypolia@abdn.ac.uk.
} 
thorny process leading to the hoped for solution. One important factor for suppressing the early optimism lay in the changing global context and the unanticipated result in the US presidential election a couple of months earlier. So, while the multilateral conference in Geneva was long scheduled on the understanding that Washington DC anticipated the Democrat nominee, Hillary Clinton, taking over Obama's White House, Donald Trump's election brought a certain degree of uncertainty to the talks regarding US foreign policy.

For over 40 years, negotiations for the reunification of the island have mainly evolved around five issues, namely: territories and 'settlers'; property; rights and freedoms; governance; and security. Positions on these issues had long been entrenched and polarised. However, arguably, there has been significant progress in three out of the five issues. Arrangements for governance and security appear to be the deal breaker.

Progress appears to have been made about territory adjustments and the issue of the 'settlers'. For the very first time, maps drawn by Cypriots were exchanged during the negotiations. The differences between maps from the two sides seemed reconcilable. In the light of the recent discovery of hydrocarbons in the Exclusive Economic Zone of the Republic Cyprus, the maps, along with the governance arrangements, gain an additional interest. The issues of property and the rights and freedoms are very complicated as the latter requires fundraising. Even so, it would not be a deal breaker.

The deal breaker issues can be considered as legacy from the colonial era and the 1958-1960 settlements. The 1960 constitution granted a flawed independence to the Republic of Cyprus. It was based on ethnic division, conferring on three foreign powers, Britain, Greece and Turkey, the right to meddle in Cypriot affairs in pursuit of their own interests. The old-school imperial Treaty of Guarantee (1960) provided for the three guarantors powers to consult in order to guarantee 'the independence, territorial integrity and security of the Republic of Cyprus'. 
For several decades the UN-facilitated settlement process has aimed to achieve a bizonal, bicommunal state with political equality. Many have criticized the irony of desiring a reunification through a plan for division. Concerns over the governance and power sharing issues usually are being raised either for their complex unviability or for being a vehicle for Turkey's entrance in the EU. This 'back door entry into the EU' warning is usually framed in an Islamophobic discourse. However difficult and unpopular could be reaching a compromise on this, it is not the issue that would blow up the deal. That would be the issue of security.

The thorniest of all is the issue of guarantor powers and security. Turkey maintains an estimated garrison of over 30,000 troops in the northern third of Cyprus while Greece has about 1,000 soldiers in the Republic of Cyprus. The proportion of 30,000 troops in relation to the civilian population of the North makes the region one of the most militarised areas of the world. Turkey's wellestablished position on the issue of troop withdrawal is that is out of the question as they act as a guarantor of stability. While the multilateral conference was held in Geneva, Recep Tayyip Erdogan, the president of the Turkish Republic, reaffirmed this position which handicapped the whole process. He stated that Turkish troops will remain in Cyprus in perpetuity. The Turkish side accused the Greek Foreign Minister Nicos Kotzias of putting additional obstacles with his insistence on the withdrawal of the Turkish troops according to an agreed deadline.

None of the parties involved wishes to suspend the process soon. However, the likelihood of reaching an agreement that would be approved by double referendums is slim. The appetite for any referendum has been reduced because of the results of recent referendums held across the EU.

It is anachronistic in the 21st century to have a system of guarantor powers which jeopardises a state's independence. For a sovereign country, these (neo)imperial arrangements are the ones that nip the negotiations in the bud. 